MICRO TOTAL ANALYSIS SYSTEMS ' 98 


\section{Micro Total Analysis Systems '98}

Proceedings of the uTAS '98 Workshop, held in Banff, Canada, 13-16 October 1998

edited by

D. JED HARRISON

Department of Chemistry,

University of Alberta,

Edmonton, Canada

and

ALBERT VAN DEN BERG

MESA Research Institute,

University of Twente,

Enschede, The Netherlands 
Library of Congress Cataloging-in-Publication Data

ISBN 978-94-010-6225-1 ISBN 978-94-011-5286-0 (eBook)

DOI 10.1007/978-94-011-5286-0

Printed on acid-free paper

Reprinted 2000

All Rights Reserved

(C) 1998 Springer Science+Business Media Dordrecht

Originally published by Kluwer Academic Publishers in 1998

Softcover reprint of the hardcover 1st edition 1998

No part of the material protected by this copyright notice may be reproduced or

utilized in any form or by any means, electronic or mechanical,

including photocopying, recording or by any information storage and

retrieval system, without written permission from the copyright owner. 
Dedicated to the late H. Michael Widmer. 


\section{Program Committee $\mu$-TAS '98}

Prof. D. Jed Harrison (Conference Chairman)

Department of Chemistry

University of Alberta

Prof. Piet Bergveld

University of Twente,

MESA Research Institute

Prof. Albert van den Berg

University of Twente,

MESA Research Institute

Prof. Nico F. de Rooij

Université de Neuchatel

Institute de Microtechnique

Dr. M. Allen Northrup

Vice President and C.T.O.

Cepheid

Prof. Andreas Manz

Imperial College, London

Department of Chemistry

Prof. Günter Fuhr

Humboldt Universität zu Berlin

Institut für Biologie

Dr. Bart H. van der Schoot

Université de Neuchatel

Institute de Microtechnique

Prof. Shuichi Shoji

Waseda University

Department of Electric and Communication Engineering

Dr. J. Michael Ramsey

Oak Ridge Laboratories 


\section{Preface}

The Micro-Total Analysis Systems ( $\mu$-TAS) Conference Program, which was first and foremost the responsibility of the contributing authors, was screened and structured by the Program Committee. There were well over 130 manuscripts submitted for about 36 oral presentations and 68 poster presentations, and 18 well recognized researchers accepted invitations to speak. This tremendous response is an indication of the significant growth in the field of miniaturized and integrated analytical systems since $\mu$-TAS ' 96 . The space and time limitations associated with a predominantly single session, workshop style meeting imposed a limitation on the number of presentations. The Program Committee was able to create a strong program of oral and poster presentations from the large number of high quality submissions.All submitted abstracts were evaluated and discussed by the Program Committee before decisions were reached. The Committee hopes that the effort to maintain a limited number of presentations and an interactive, workshop style format will ensure an informative and enjoyable meeting for all attendees. Personally, I wish to thank the Program Committee members for their effort and their generous donation of time and resources to this process.

No Conference or Meeting can occur without the effort of a great many people contributing to its planning, organization and funding. The number of people I wish to thank for their contributions is large: first Allen Northrup for his assistance in fund raising for the meeting, next Amanda Rahn and Laura MacDougall for their assistance with planning, day to day organization and contact management over the past year, and Amanda for her handling of the Abstract submissions, mailings and Proceedings manuscripts, Gregor Ocvirk who contributed most of the art work needed for the brochures and for this volume, Loranelle Shultz-Lockyear for acting as a sounding board and organizer, all of my research group, who performed numerous tasks, the most onerous being assembly of the large volume mailings (including Said Attiya, Youssouf Badal, Abebaw Belay Jemere, Nicolas Bings, Siew Bang Cheng, Nghia Chiem, Guifeng Jiang, Mark Munroe, Charmaine Qiu, Cameron Skinner, Hossein Salimi-Moosavi, Thompson Tang, Can Wang), Patricia Conway for her organization of a special session on commercialization strategies, Albert van den Berg for his expert arrangement of the assembly and printing of this volume, and a number of others for helpful advice, suggestions and contributions. I also thank the Conference Steering Committee for agreeing to my bid to move the meeting to North America for 1998, holding it here in Banff under my Chairmanship.

I would like to dedicate this Proceedings volume to the memory of the late Professor Dr. Michael Widmer. Michael was the Chairman of $\mu$-TAS '96. He was an important figure in the early development of the $\mu$-TAS concept, developing the total analysis system concept for process control and providing guidance, assistance and shelter for the initial technology development within the research labs of Ciba-Geigy, Switzerland. Many of those currently working in the field have had the good fortune to work with him, benefit from interactions with him and his research group, or come into contact with him and his broad range of contributions to Analytical Chemistry. On behalf of all of those who have known Michael Widmer I would like to express our gratitude for his many and varied contributions.

The six years since $\mu$-TAS ' 94 have seen remarkable developments and expansion of miniaturized instrumentation for chemical, biochemical and biological analysis and sample processing. In fact, the concept has grown to encompass analysis and synthesis for applications ranging from chemistry through to biology, with a high degree of parallelism for high sample throughput. Applications of micro-systems in genetic analysis, clinical diagnostics, chemical synthesis, drug discovery, portable instrumentation and industrial process control provide the drivers for continued research and development. The large degree 
of industrial participation in this very young field speaks to the apparent high value of microfluidics and microinstrumentation for practical applications. The number of companies with presentations at this meeting, or which supported the meeting financially, that did not even exist at the time of the first $\mu$-TAS meeting in 1994 is striking.

Evaluating the trends seen in the work presented here at $\mu$-TAS ' 98 , two main schemes for miniaturized fluidic systems have become apparent. In one method, conveniently referred to as array based systems, sample or reagent is immobilized in large arrays on a plate or chip and fluids are flushed over the surface. In the other, microfluidic channels form complex manifolds for fluid manipulation and controlled delivery of samples and reagents; these are often referred to as microfluidic systems. These two approaches are both competitive and complementary, as demonstrated by their merger into a larger system for genetic analysis in papers presented in this volume. Inclusion of array based systems within the $\mu$-TAS concept appears to be well established now.

Several other current themes become apparent when reflecting upon the presentations at $\mu$-TAS '98. Applications, rather than fabrication methods, appear to be the primary interest of researchers in this field. This focus has engendered a much broader exploration of materials outside of those normally compatible with integrated circuit technologies than has been seen in the parent Micro-Electromechanical Systems (MEMS) community. In particular, $\mu$-TAS ' 98 sees extensive developments in the field of plastic microfabrication, the subject of only one or two pioneering papers at $\mu$-TAS ' 94 and ' 96 , due to the demand for single use disposable products in diagnostic applications. The most dominant application at $\mu$-TAS '98 is clearly genetic analysis, reflecting the value of parallel analysis in genetics and the ability of microfabrication methods to potentially meet this need. Various chemical and biochemical analyses remain the focus of significant effort, but applications in drug discovery, cell biology and in chemical synthesis represent exciting and powerful new trends that greatly extend the range of applicability of microfluidic systems. The dominance of electrokinetically pumped systems remains apparent, yet the application of sophisticated approaches to prepare better pumps and valves for microfluidic systems is evidently beginning to produce functionally useful components.

Two key issues of difficulty for $\mu$-TAS have been the detection of the necessarily small amounts of sample, and interfacing the chip based fluidic device to the external environment for sample, reagent and solvent delivery. Progress is being made on these problems, as evidenced by the presentations on integrating micro-optics or electrochemical detection with microfluidic devices, and others on sample interfacing with quick-fit connectors, low dead volume connectors and continuous sampling elements. The interfacing of microfluidic systems with the mass spectrometer requires a good interfacial connection method, as indicated by several papers augers well for the future of this powerful combination of integrated sample processing and information rich analysis.

Many other exciting ideas, concepts and applications are identified by the authors in the following pages, and their lack of inclusion in this discussion is only due to limits of space and time. I invite the conference attendees to enjoy this meeting and extract all they can from the opportunity to interact personally with many of the leading researchers in this growing field. I trust that future readers of this Proceedings volume will find it to be a highly useful snapshot of the current state of the art and the future goals of a major fraction of the pioneers in microfluidics, arrays and $\mu$-TAS.

\section{Jed Harrison}

$\mu$-TAS '98 Chairman

July 22, 1998 


\section{Contents}

\section{Day 1}

Microsystems for genetic analysis

DNA Analysis with Capillary Array Electrophoresis Microplates.

R.A. Mathies, P.C. Simpson, A.T. Woolley

Continuous Flow PCR on a Chip.

M.U. Kopp, M.B. Luechinger, A.Manz

Advances in Integrated Genetic Analysis

R.C. Anderson, G.J. Bogdan, A. Puski, X. Su

\section{Themes in $\mu$-TAS today}

Photo-Polymer Microchannel Technologies and Applications.

P. Renaud, H. van Lintel, M. Heuschkel, L. Guérin

\section{Interconnections and sample interfaces}

Parallel Separations in Microfabricated Channels with Capillary Electrophoretic

Sample Introduction.

A.G. Ewing

Novel Interconnection and Channel Technologies for Microfluidics.

N.J. Mourlas, D. Jaeggi, A.F. Flannery, B. L. Gray, B.P. van Drieënhuizen,

C.W. Storment, N.I. Maluf, G.T.A. Kovacs

A $\mu$-TAS Based on Microdialysis for On-line Monitoring of Clinically Relevant

Substances.

S. Böhm, W. Olthuis, P. Bergveld

Microdevices for Electrospray Mass Spectrometry.

F. Foret, H. Liu, B. Zhang, C. Felten, B.L. Karger

\section{Fluid mobilization and control}

Cell Sorting in Microfluidic Systems.

P. Telleman, U.D. Larsen, J. Philip, G. Blankenstein, A. Wolff

Electrohydrodynamic Pumps for High-Density Microfluidic Arrays. 45

S.E. McBride, R.M. Moroney, W. Chiang

Electrokinetic Generation of High Pressures using Porous Microstructures.

P.H. Paul, D.W. Arnold, D. J. Rakestraw

Studies of Hydrostatic Pressure Effects in Electrokinetically Driven $\mu$-TAS.

G. Boer, A. Dodge, K. Fluri, B.H. van der Schoot, E. Verpoorte, N.F. de Rooij

\section{Poster session I}

An Electronic Nose Based on a Micromechanical Cantilever Array.....

H.P. Lang, F.M. Battiston, M.K. Baller, R. Berger, J.-P. Ramseyer, P. Fornaro,

E. Meyer, H.-J. Güntherodt, C. Andreoli, J. Brugger, M. Despont, P. Vettiger,

J.-H. Fabian, T. Mezzacasa, L. Scandella, Ch. Gerber, J.K. Gimzewski

Chemical Analysis Based on Environmentally Sensitive Hydrogels and Optical

Diffraction

J. Schumacher, M. Ranft, T. Wilhelm, R. Dahint, M. Grunze 
Mass-Sensing Multianalyte Micro-Array Based Immunoassay by Direct NIR Fluorescence and Quantitative Image Analysis.

J.W. Silzel, C. Dodson, R.J. Obremski, T. Tsay

Biology Lab-on-a-Chip for Drug Screening

H. Salimi-Moosavi, R. Szarka, P. Andersson, R. Smith, D.J. Harrison

Results Obtained Using a Prototype Microfluidics-Based Hematology Analyzer.

E. Altendorf, D. Zebert, M. Holl, A. Vannelli, C. Wu,T. Schulte

Rare Event Cell Sorting in a Microfluidic System for Application in Prenatal Diagnosis..... 77 A.Wolff, U.D. Larsen, G. Blankenstein, J. Philip, P.Telleman

Simultaneous Self-Referencing Analyte Determination in Complex Sample Solutions using Microfabricated Flow Structures (T-Sensors $\mathbf{T M}$ )

B.H. Weigl, J. Kriebel, K. Mayes, P. Yager, C.C. Wu, M. Holl,M. Kenny, D. Zebert

Fabrication of Injection and Switching Micro Valve for Whole Blood Control.

K. Miura, S. Shoji

A Microfluidics-Based Microcytometer: Interfacing Microfluidics with Macrofluidics

M. Tracey, I. Johnston, R. Greenaway, J. Davis, N. Sutton, G. Schulze, W. Doetzel

Microfabricated Biosensors for Measuring Neurotransmitters from Cultured Nerve Cells... 93

O. Niwa, R. Kurita, T. Horiuchi, K. Torimitsu

Anti-Resonant Reflecting Optical Waveguides (ARROWS) as Optimal Optical Detectors

for $\mu$ TAS Applications

N.J. Goddard, K. Singh, F. Bounaira, R.J. Holmes, S.J. Baldock, L.W. Pickering,

P.R. Fielden, R.D. Snook

Probe Beam Deflection of Isotachophoresis on Miniaturised Planar Glass Devices

L.W. Pickering, S.J. Baldock, P.R. Fielden, N.J. Goddard, R.D. Snook,

B.J. Treves Brown

Integration of Microelectrodes with Etched Microchannels for In-Stream

Electrochemical Analysis.

R. B. Darling, P. Yager, B. Weigl, J. Kriebel, K. Mayes

On-line Detection of Electrophoretic Separations on a Microchip

by Raman Spectroscopy.

K.A. Reshni, M.D. Morris, B.N. Johnson, M.A. Burns

Electrophoretic Separations in Ultrathin Channels Using Microelectrode

Array Detection.

S. Suljak, L. Thompson, A. Ewing

Micromechanical Thermogravimetry on Single Zeolite Crystals.

J.-H. Fabian, R. Berger, H.P. Lang, Ch. Gerber, J. K. Gimzewski, J. Gobrecht,

E. Meyer, L. Scandella

A One-Spot Electrochemical Transducer for use in $\mu \mathrm{TAS}$.

J. Hendrikse, G.F. Dirks, W. Olthuis, P. Bergveld

Various Current Regimes Applicable for Sensing in $\mu$ TAS.

W. Olthuis, S. Böhm, C. Neagu, P. Bergveld 
Optimization of a Porous Silicon Carrier Matrices Applied in Chip Based Micro-

Enzyme Reactors.

J. Drott, M. Bengtsson, L. Rosengren, T. Laurell

Electrochemical Fabrication of Multi Walled Micro Channels.

R. Tjerkstra, J.G.E. Gardeniers, M.C. Elwenspoek, A. van den Berg

Utilizing the $\{111\}$ Plane Switch-Over Etching Process for Micro Fluid

Control Applications.

R. E. Oosterbroek, J.W. Berenschot, S. Schlautmann, T.S.J. Lammerink,

A. van den Berg, M.C. Elwenspoek

Coupling Electrospray Mass Spectrometry to Microfluidic Devices with

Low Dead Volume Connections.

N.H. Bings, C.D. Skinner, C. Wang, C.L. Colyer, D.J. Harrison, J. Li, P. Thibault

Silicon-Micromachined Separation Columns Coated with Amino Acid Films

for an Integrated On-chip Gas Chromatograph.

S. Hannoe, I. Sugimoto, T. Katoh

Computer Simulations for Microchip Electrophoresis.

S.V. Ermakov, S.C. Jacobson, J.M. Ramsey

Electrophoretic Separation of Antisense DNA using Polymer-solution filled

Capillary by Cross-Injection.

S.-H. Chen, Y.-C. Lin, Y.-H. Chen, H.-S. Liao, C.-Y. Wu, S.-H. Wang

Integrated Serial Dilution on a Microchip for Immunoassay Sample Treatment

and Flow Injection Analysis

S.B. Cheng, C.D. Skinner, D.J. Harrison

Minimizing Dispersion Introduced by Turns on Microchips.

C. T. Culbertson, S.C. Jacobson, J.M. Ramsey

Use of Surfactant Additives for Modification of Electroosmotic Flow

and Wall Chemistry.

C.A. Lucy, K.K.-C. Yeung

Sample Matrix Effects on Injection and Sample Loading in Integrated

Capillary Electrophoresis Devices.

L. Shultz-Lockyear, C. Colyer, K. Roy, D.J. Harrison

Development of a Microfabricated Biochemical Workbench -

Improving the Mixing Efficiency....

T. Fujii, K. Hosokawa, S. Shoji, A. Yotsumoto, T. Nojima, I. Endo

Micro Mixer Incorporated with Piezoelectrically Driven Valveless Micropump.

Z. Yang, H. Goto, M. Matsumoto, T. Yada

Liquid Mixing Studies with an Integrated Mixer/Valve.

J. Voldman, M.L. Gray, M.A. Schmidt

Fabrication of an Integrated Mixing/Reaction Micro Flow Cell for $\mu$-TAS.

A. Yotsumoto, R. Nakamura, S. Shoji, T. Wada

Micro-fluidic Diffusion Coefficient Measurement.

P. Galambos, F.K. Forster 


\section{Day 2}

\section{Cells on chips}

Sizing, Fractionation and Mixing of Biological Objects via Microfabricated Devices.

O. Bakajin, R. Carlson, C.F. Chou, S.S. Chan, C. Gabel, J. Knight, T. Cox, R.H. Austin

Individual Embryo Transport and Retention on a Chip.

I.K. Glasgow, H.C. Zeringue, D.J. Beebe, S.-J. Choi, J.T. Lyman, M.B. Wheeler

Single Cell Enzymatic Analysis on a Microchip: Lysing of Single Cells and Identification of their $\beta-$ Galactosidase Activity.

G. Ocvirk, H. Salimi-Moosavi, R.J. Szarka, E. Arriaga, P.E. Andersson,

R. Smith, N. J. Dovichi, D.J. Harrison

Applying Microfluidic Chemical Analytical Systems to Imperfect Samples

Paul Yager, D. Bell, J.P. Brody, D. Qin, C. Cabrera, A. Kamholz, B. Weigl

\section{Array based technologies}

Building Highly Diverse Arrayed Substance Libraries by Micro Offset Printing.

E. Ermantraut, T. Schulz, J. Tuchscheerer, S. Wölfl, H.-P. Saluz, E. Thallner,

J. M. Köhler

Fluorescence Array Biosensor - Biochemistry and Application.

F.S. Ligler, C.A. Rowe, S. Balderson, M. Feldstein, J.P. Golden

An Integrated Microelectronic Hybridization System for Genomic Research

and Diagnostic Applications

M.J. Heller, A. Holmsen, D. Ackley, G. Tu, R. Sosnowski, B. Butler, P. Dillion,

$M$. Nerenberg, D. Raymond, E. Sheldon, J. Cheng, R. Rooney, B. Mather, J. O'Connell

\section{Microfluidic systems for assays}

Development of a Generic Microfluidic System for Electrochemical

Immunoassay-Based Remote Bio/Chemical Sensors.

C.H. Ahn, T. Henderson, W.Heineman, B. Halsall

Integrated Microsystem for Sample Introduction, Mixing, Reaction, Separation and

Self Calibration of Immunoassays..

S. Attiya, X. C. Qiu, G. Ocvirk, N. Chiem, W.E. Lee, D.J. Harrison

Continuous-flow vs. Batch Process - a Few Examples.

A. Manz, F. Bessoth, M.U. Kopp

\section{Microfabrication in plastic}

Micro-TAS on Polymer Substrates Micromachined by Laser Photoablation

A. Schwarz, J.S. Rossier, F. Bianchi, F. Reymond, R. Ferrigno, H.H. Girault

Key Elements of a Transparent Teflon ${ }^{\circledR}$ Microfluidic System.

L.P. Lee, S.A. Berger, L. Pruitt, D. Liepmann

An Inexpensive Plastic Technology for Microfabricated Capillary Electrophoresis Chips 249 J. R. Webster, M.A. Burns, D.T. Burke, C.H. Mastrangelo

Microfluidic Manifolds by Polymer Hot Embossing for $\mu$-TAS Applications

H. Becker, W. Dietz, P. Dannberg

Multiplexed, Disposable, Plastic Microfluidic Systems for High-Throughput Applications 257 T.D. Boone, H.H. Hooper 


\section{Day 3}

\section{DNA analysis on microchips}

Micro-Genetic Analysis Systems.

T.B. Taylor, P.M. St. John, M. Albin

A Microfabricated Fluidic Reaction and Separation System

for Integrated DNA Analysis.

S.N. Brahmasandra, B.N. Johnson, J.R. Webster, K. Handique, D.T. Burke,

C.H. Mastrangelo, M. A. Burns

High Performance DNA Separations in Microchip Electrophoresis Systems

L. Bousse, B. Dubrow, K. Ulfelder

Nucleic Acid Concentration and PCR for Diagnostic Applications

L.A. Christel, K. Petersen, W. McMillan, M.A. Northrup

\section{Micro optics and detection}

Microoptical Fluorescence Detection for Chip-Based Multiplexed Analysis Systems.

A.E. Bruno, E. Baer, R. Völkel, C.S. Effenhauser

Micro-Optical Systems for Fluorescence Detection in $\mu$-TAS Applications.

J.-C. Roulet, K. Fluri, E. Verpoorte, R. Völkel, H.-P. Herzig, N.F. de Rooij,

R. Dändliker

Integrated Bio/Chemical Microsystems Employing Optical Detection: A Cytometer.

O. Leistiko, P. F. Jensen

Photothermal Ultrasensitive Detection and Microchemistry

in the Integrated Chemistry Lab.

T. Kitamori, M. Fujinami, T. Odake, M. Tokeshi, T. Sawada

\section{Fluid control concepts}

Impedances for Design of Microfluidic Systems

R.L. Bardell, F.K. Forster

Miniaturized Electrocaloric Flow Controller for Analyte Muliplexing and Cell/Particle Sorting....

T. Schulz, S. Poser, E. Ermantraut, J. McCaskill, H. Mathis, J. M. Köhler

Hydrophobic Microcapillary Vent for Pneumatic Manipulation of Liquid in $\mu$-TAS.

K. Hosokawa, T. Fujii, I. Endo

Microfabricated Chips for Capillary Electrophoresis on Quartz Glass Substrates

Using a Bonding with Hydrofluoric Acid.

T. Nishimoto, H. Nakanishi, H. Abe, A. Arai, R. Nakamura, A. Yotsumoto, S. Shoji

\section{Micro chip based electrophoresis}

Rapid Electrophoretic and Chromatographic Analysis on Microchips

S.C. Jacobson, J.P. Kutter, C.T. Culbertson, J. M. Ramsey

Free Flow Electrophoresis Module Fabricated with Pyrex Glass.

E. Shinohara, N. Tajima, H. Suzuki, K. Kano 
A Miniaturized Planar Isotachophoresis Separation Device for Transition Metals with Integrated Conductivity Detection.

P.R. Fielden, S.J. Baldock, , N.J. Goddard, L.W. Pickering, J.E. Prest,

R.D. Snook, B.J. Treves Brown, D.I. Vaireanu

Characterization of Silicon-Based Insulated Channels for Capillary Electrophoresis.

Y. Fintschenko, P. Fowler, V. Spiering, G.-J. Burger, A. van den Berg

Novel Microfabricated Capillary Array Electrophoresis Chip Fabricated by

Synchrotron Radiation \& Direct Observation of Dynamics of DNA Molecules

Migrating in Microchannels.

Y. Baba, O. Tabata

\section{Poster session II}

Continuous Flow versus Stopped Flow in a Micro Flow Injection System

E.B. van Akker, M. Bos, A. van den Berg, W.E. van der Linden

Microfabricated Channels and Fluid Control Systems for Integrated

Flow Injection Analysis.

M. Fujinami, M Tokeshi, T. Odake, T. Kitamori, K. Sato, T. Sawada,

K. Matsumoto, M. Nakao, T. Ooi, Y. Hatamura

Microfabricated Dual-Microdialysis and Capillary Isoelectric focusing Devices

for Cleanup and Separations/ Mass Spectrometric Anyalysis of Biomolecules

Y. Lin, N. Xu, J. Wen, D. Matson, R.D. Smith

Chip-based Heterogeneous Immunoassay for Clinical Diagnostic Applications.

K. Fluri, G.-L. Lettieri, B.H. van der Schoot, E. Verpoorte, N.F. de Rooij

Micro-Analytical ( $\mu$ FIA) Reactor for the Determination of

Phosphate as Orthophosphate.....

G.N. Doku, S.J. Haswell

Investigation of Chemiluminescent MicroAnalytical Systems.

L.J. Nelstrop, G.M. Greenway, S.N. Port

Isotachophoresis on Planar Polymeric Substrates.

S.J. Baldock, N. Bektas, P.R. Fielden, N. J. Goddard, L.W. Pickering, J.E. Prest,

R.D. Snook, B.J. Treves Brown, D.I. Vaireanu

Application of Thin Cross-Linked Gelatin Layers in Micro Systems Technology

K. Wohlfart, E. Ermantraut, J.M. Köhler

Plastic Microfluid Devices for Clinical Measurements.

L.E. Locascio, M. Gaitan, J. Hong, M. Eldefrawi

Fabrication Processes for Polymer-based Microfluidic Analytical Devices.

D.W. Matson, P.M. Martin, W.D. Bennett, D.E. Kurath, Y. Lin, D. Hammerstrom

$\mu$-Structured Polymers as Components of Chemical Microreactors

H.-G. Braun, E. Meyer, T. Kratzmüller

Development of Microfabricated Valves for $\mu$ TAS.

H. Hartshorne, Y. Ning, W.E. Lee, C. Backhouse

A Silicon Micropump with a High Bubble Tolerance and Self-Priming Capability

P. Woias, R. Linnemann, M. Richter, A. Leistner, B. Hillerich 
Flow-through Microdispensing; Design and Applications.

J. Nilsson, L. Wallman, P. Önerfjord, G. Marco-Varga, T. Laurell

Manufacturing of Self-Priming Plastic Micropumps.

S. Böhm, M. Dierselhuis, W. Olthuis, P. Bergveld

Micromachined Bi-directional Liquid Pump with Thermally Controlled DynamicValves. 395 S. Matsumoto, A. Klein, R. Maeda

Micro Ball Valve for Fluidic Micropumps and Gases

O. Krusemark, A. Feustel, J. Müller

Nanomanipulation Techniques Inside the SEM - First Attempts to Integrate

Microfabrication into a SEM.

E. Meyer, H.-G. Braun

Fluidics for a Multi-analyte Detector Based on Intermolecular Binding Forces.

C.R. Tamanaha, D.R. Baselt, P.E. Sheehan, R.J. Colton

Reagent Handling by Manipulation of Magnetic Particles: A New Approach to the

Automation and Miniaturization of Analytical Chemistry

S. Ostergaard, G. Blankenstein, H. Dirac, O. Leistiko

Novel DNA Manipulation Based on Local Temperature Control:

Transportation and Scission.

K. Hirano, R. Ishii, S. Matsuura, S. Katsura, A. Mizuno

Numerical Simulation of Magnetic Separation of Particles in a Rectangular

Microchannel.

S. Lomholt, J.-P. Lynov, P. Telleman

Automated Microchip Platform for Biochemical Analysis

W.E. Lee, D.E. Bader, D.J. Harrison, T. Tang, N. H. Chiem, X. C. Qui,

S. Attiya, C.D. Skinner, H. Mottl, M. Paulson, G. Burchett, G. McKinnon, Y. Ning,

F. Bekkaoui, D. Mah

Automatic Sensor System for Water Analysis.

A. Ehlert, S. Büttgenbach

Fluorescence Array Biosensor - Part 1: Optics and Fluidics.

M.J. Feldstein, J.P. Golden, F.S. Ligler

Microseparations and Microfluidic Studies.

D.W. Arnold, C.G. Bailey, M.G. Garguilo, C.M. Matzke, J. R. Wendt,

W.C. Sweatt, S.H. Kravitz, M.E. Warren, D.J. Rakestraw

$\mu$ TAS for Volumetric or Coulometric Titrations of Nanomole Amounts of Analytes in Microliter Samples.

O.T. Guenat, W. E.Morf, E. Verpoorte, B.H. van der Schoot, N.F. de Rooij.

System Requirements for a Portable Cell Based Sensor.

B.D. Debusschere, D.A. Borkholder, G.T.A. Kovacs

Laboratory on Chip for Clinical Applications.

I. Moser, G. Jobst, G. Urban 
Day 4

Future themes in micro-TAS I

Microfabricated Liquid Chromatography Columns Based on Collocated

Monolith Suppport Structures.

B. He, F. Regnier

Towards a Modular Microfluidic System for Proteome Analysis by Mass Spectrometry... 457

D. Figeys

\section{Future themes in micro-TAS II}

Integrated Gas Phase Microreactors

Klavs F. Jensen, S.L. Firebaugh, A.J. Franz, D. Quiram, R. Srinivasan, M.A. Schmidt

In Situ Detection of Cells and Biochemical Reactions by Optical Diffraction.

F. Morhard, R. Dahint, M. Grunze

Micromachined Flame Analysers (Atomic Emission Flame Spectrometer (AES)

Flame Ionization Detector (FID))

S. Zimmermann, B. Ripenhusen, J. Müller

Integrated Chemical Analysis Systems for Gas Phase CW Agent Detection

G. C. Frye-Mason, R.J. Kottenstette, E.J. Heller, C. M. Matzke, S.A. Casalnuovo,

P.R. Lewis, R.P. Manginell, W. K. Schubert, V.M. Hietala, R.J. Shul

Authors index

Subject index. 